\title{
Polityka państwa wobec upowszechnienia elastycznych form zatrudnienia w Polsce
}

\section{Streszczenie}

W czerwcu 2015 r. Sejm przyjął nowelizację Kodeksu pracy ${ }^{1}$, zgodnie z którą wprowadzone zostaje ograniczenie łącznego czasu trwania umów o pracę na czas określony zawieranych z jednym pracodawcą do 33 miesięcy, o ile nie istnieją obiektywne powody, aby tego typu kontrakt został zawarty na dłuższy okres. Zmiany, które wejdą w życie 22 lutego 2016 r., obejmują również m.in. zrównanie czasu trwania okresów wypowiedzenia między umowami terminowymi i na czas nieoznaczony - dotychczas w umowie o pracę na czas określony zawieranej na sześć miesięcy lub dłużej można było zawrzeć klauzulę o możliwości jej rozwiązania z dwutygodniowym wypowiedzeniem. Zmiana przepisów jest reakcją na rozpowszechnienie w Polsce praktyki zatrudniania na podstawie umów terminowych. Osiągnęło to skalę niespotykaną w innych krajach Unii Europejskiej. Nowe regulacje mogą spowodować, że po raz pierwszy od kilku lat udział zatrudnionych na czas określony wśród pracowników najemnych może ulec zmniejszeniu.

Problem nadmiernego udziału elastycznych form zatrudnienia doczekał się w ostatnich latach w Polsce bogatej literatury. Stał się przedmiotem badań ekonomistów i socjologów oraz dyskusji specjalistów prawa pracy. Popularność elastycznych form zatrudnienia spotkała się również z aktywną krytyką ze strony związków zawodowych, co znalazło odbicie w mediach - dość wspomnieć o karierze terminu „umowy śmieciowe” począwszy od 2012 r. Autor podejmuje próbę syntetycznego omówienia problemu elastycznych form zatrudnienia, obejmującego kwestie: przyczyn ich popularności wśród pracodawców, intensywności stosowania różnych form zatrudnienia na podstawie dostępnych danych, kształtu przepisów ochronnych krajowego prawa pracy i praw pokrewnych regulujących zawieranie różnego rodzaju umów na rynku pracy w świetle wymogów stawianych przez Unię Europejską i Międzynarodową Organizację Pracy, a także społecznych i ekonomicznych konsekwencji stosowania elastycznych form zatrudnienia.

Słowa kluczowe: polityka rynku pracy, formy zatrudnienia, elastyczność, stosunki pracy, polityka gospodarcza

1 Projekt ustawy o zmianie ustawy - Kodeks pracy oraz niektórych innych ustaw (z dnia 19 marca 2015 r. - w wersji na Radę Ministrów), www.mpips.gov.pl/bip/projekty-aktow-prawnych/projekty-ustaw/prawo-pracy/projekt-ustawy-o-zmianie-ustawy---kodeks-pracy-oraz-niektorych-innych-ustaw-1/ \#akapit4, dostęp 30.03.2015. 


\title{
The policy of the state in the face of the widespread phenomenon of flexible forms of employment in Poland
}

\begin{abstract}
In June 2015 the Ministry of Labour and Social Policy announced an amendment to the Labour Code, which is the reaction to the prevalence of employment based on-fixed term contracts in Poland. The scale of this phenomenon is not observed in any other E.U. state. New regulations may result in a decrease in the share of fixed-term employees of the total number of employees to be observed in the last few years.

The Ministry intends to replace the limit of the renewals of a job contract concluded with an employee (currently the second renewal of the contract results in the conclusion of a permanent job contract) with another restriction: the total duration of such contracts should not exceed 33 months.

The problem of an excessive share of flexible forms of employment has been widely analysed in the literature in recent years. It has become the subject of studies in the area of economy and sociology as well as an issue addressed by labour law experts. The expansion of flexibility has also received criticism from the trade unions, which influenced the mass media discourse - it is enough to mention the popularity of the term 'junk contracts' since 2012.

The author attempts to comprehensively analyse the problem of flexible forms of employment, which include such issues as: the reasons for their popularity among employers, the scale of the use of particular forms based on the available statistical data, the construction of protective regulations of domestic labour law in the light of the requirements resulting from the E.U. and the I.L.O. membership, as well as social and economic consequences of the use of flexible forms of employment.
\end{abstract}

Keywords: labour market policy, forms of employment, flexibility, industrial relations, economic policy

Elastyczność rynku pracy jest pojęciem wieloznacznym. W tym artykule jest ona rozumiana przede wszystkim jako swoboda zawierania i rozwiązywania umów na rynku pracy. Dzięki nim pracodawcy mają możliwość łatwego dostosowywania wielkości zatrudnienia w przedsiębiorstwie do aktualnego zapotrzebowania na nie. W literaturze przedmiotu jest mowa o elastyczności numerycznej, ilościowej lub zatrudnienia ${ }^{2}$.

Firmy dążą do zapewnienia sobie swobody w zakresie kształtowania wielkości zatrudnienia, co wynika z wielu czynników, takich jak wzrost konkurencji na coraz

2 E. Kryńska, Elastyczność zatrudnienia na polskim rynku pracy, „Polityka Społeczna” 2007, nr 11-12, s. $1-8$. 
bardziej globalnych rynkach i niepewność wynikająca z wahań popytu, szczególnie w obecnym okresie spowolnienia gospodarczego. Ponadto doszło do ewolucji systemu produkcji: od tak zwanego fordyzmu, który preferuje większą stabilność zatrudnienia (opierała się na nim powojenna gospodarka państw wysoko rozwiniętych), do postfordyzmu, czy też - jak określa współczesny system produkcji M. Castells - informacjonizmu3 ${ }^{3}$ W nowym systemie ma miejsce dominacja sektora usług i wykorzystanie w walce konkurencyjnej najnowocześniejszych technologii. Ponadto firmy - działające w warunkach wysokiej niepewności - dążą do przerzucania części ryzyka biznesowego na swoich pracowników. Tę tendencję wzmaga presja ze strony gospodarki państw rozwijających się, dysponujących wielomilionową rzeszą nisko opłacanych pracowników. W świetle neoklasycznej teorii przedsiębiorstwa racjonalnym środkiem radzenia sobie z globalizacją konkurencji i nieprzewidywalnością popytu jest dążenie do obniżania ochrony zatrudnienia oraz możliwości renegocjacji jego warunków ${ }^{4}$.

Reformy prawa pracy w wielu państwach świata w okresie ostatnich kilku dziesięcioleci właśnie tej tendencji sprzyjały. Wprawdzie przedsiębiorstwa zabiegają o lojalność swoich kluczowych pracowników (wysokiej klasy specjalistów), ale obok nich funkcjonują również pracownicy, w wypadku których koszt zwolnienia, a następnie ponownej rekrutacji jest niższy, niż wynikający z utrzymywania stanowiska pracy w okresie spadku zamówień. Podobnie ową segmentację personelu firm wyjaśnia teoria elastycznej struktury ${ }^{5}$. Zgodnie z tą koncepcją pracownicy przedsiębiorstwa dzielą się na trzy grupy:

- wysokiej klasy specjalistów zatrudnianych na podstawie umów zapewniających ochronę trwałości stosunku pracy,

- specjalistów pracujących na kontraktach terminowych,

- dorywczo zatrudnianych pracowników o niskich kwalifikacjach.

Podziały te przenoszą się na poziom makrospołeczny - rynki pracy stają się dualne. Obok tzw. segmentu rdzeniowego, obejmującego wykwalifikowanych pracowników zatrudnianych na korzystnych, stabilnych warunkach, występuje segment peryferyjny, skupiający niskowykwalifikowanych pracowników, którzy nie mogą liczyć na stabilność zatrudnienia i satysfakcjonujące warunki'. To z kolei prowadzi do znaczących różnic statusu ekonomicznego i społecznego, przekładając się na kształt struktury społecznej. Stąd m.in. koncepcja prekariatu jako nowej klasy społecznej

3 M. Castells, Społeczeństwo sieci, Wydawnictwo Naukowe PWN, Warszawa 2010.

4 M. Bednarski, Zatrudnienie na czas określony. Perspektywa pracodawców, w: Zatrudnienie na czas określony w polskiej gospodarce, red. M. Bednarski, K.W. Frieske, IPiSS, Warszawa 2012, s. 36-66.

5 Ibidem. Zob. także: L. Machol-Zajda, Rozwój elastycznych form pracy, „Zarządzanie Zasobami Ludzkimi” 2008, nr 5, s. 11-27.

6 K.W. Frieske, Dwa oblicza rynku pracy, w: A. Kojder, Jedna Polska? Dawne i nowe zróżnicowania Społeczne, Wydawnictwo WAM, Kraków 2007, s. 437-452. 
czasowych i nisko opłacanych pracowników pozbawionych wielu przywilejów socjalnych klasy średniej.

\section{Neoliberalna recepta}

W wielu państwach, począwszy od lat 70. ubiegłego wieku, następowały zmiany przepisów rynku pracy, które zmierzały do osłabiania ochrony zatrudnienia. Było to zgodne z neoliberalną "receptą" radzenia sobie z kryzysami ekonomicznymi i wywoływanym przez nie bezrobociem. Rządy wręcz konkurowały skalą liberalnych zmian o napływ (lub pozostanie w granicach państwa) coraz bardziej mobilnego kapitału inwestycyjnego generującego miejsca pracy ${ }^{8}$. Rezultatem takiej polityki była coraz silniejsza segmentacja rynku pracy i nadużywanie przez firmy atypowych form zatrudnienia.

Polska posiada szczególnie dużą grupę pracujących na podstawie elastycznych umów. Można by przypuszczać, że nie powinno do tego dojść, ponieważ nie narzucamy - w stosunku do innych krajów - nadmiernej ochrony stałego zatrudnienia. Według danych OECD z 2013 r. wskaźnik EPRC, informujący o stopniu ochrony stałych pracowników przed zwolnieniami - zarówno indywidualnymi, jak i grupowymi - osiągał w Polsce wartość przeciętną na tle innych państw objętych badaniem -2,4. Najsilniejszą ochroną zatrudnienia wśród państw Unii Europejskiej charakteryzowały się Niemcy $(3,0)$, na dalszych zaś miejscach znalazły się: Belgia i Holandia $(2,9)$, Francja i Włochy $(2,8)$ oraz Luksemburg, Portugalia, Słowenia i Czechy $(2,7)$. Na ochronę przed zwolnieniami w najmniejszym stopniu mogli liczyć stali pracownicy w Wielkiej Brytanii $(1,6)$, Irlandii, Estonii i na Węgrzech $(2,1)$ oraz w Finlandii $(2,2)$ i na Słowacji.

Widać więc, że wśród państw chroniących trwałość zatrudnienia stałych pracowników przeważają te o konserwatywnym modelu państwa opiekuńczego według klasyfikacji G.E. Andersena, podczas gdy wśród tych z niskim poziomem ochrony nadreprezentowane są kraje o modelu liberalnym lub należące do byłego bloku wschodniego'.

Również poza obszarem Unii Europejskiej szczególnie duża swoboda w zakresie zwolnień obowiązuje w krajach anglosaskich (USA, Nowa Zelandia, Kanada), podczas gdy - co ciekawe - rekordowo wysoki poziom ochrony trwałości zatrudnienia

7 G. Standing, Prekariat. Nowa niebezpieczna klasa, Wydawnictwo Naukowe PWN, Warszawa 2014.

8 Ibidem.

9 Zob. G. Esping-Andersen, Trzy światy kapitalistycznego państwa dobrobytu, Difin, Warszawa 2010. 
standardowego obserwuje się w Chinach, zaś wśród państw bardziej restrykcyjnych w tej dziedzinie od Polski figuruje Rosja.

\section{Polskie rekordy w Unii Europejskiej}

Pracodawcy w Polsce szczególnie często wykorzystują terminowe umowy o pracę. Są one objęte przepisami Kodeksu pracy, który przewiduje możliwość zawarcia takiej umowy na czas określony, czas wykonywania określonej pracy, a także w razie zastępowania pracownika czasowo nieobecnego (umowa na zastępstwo) lub zatrudniania nowego pracownika (umowa na okres próbny). Zgodnie z wynikami badania Labour Force Survey, odsetek osób pracujących na podstawie umów terminowych wśród ogółu pracujących był w Polsce w 2013 r. najwyższy spośród wszystkich państw Unii Europejskiej - wynosił 26,8\%. Szczegółowe dane zaprezentowano na rysunku 1.

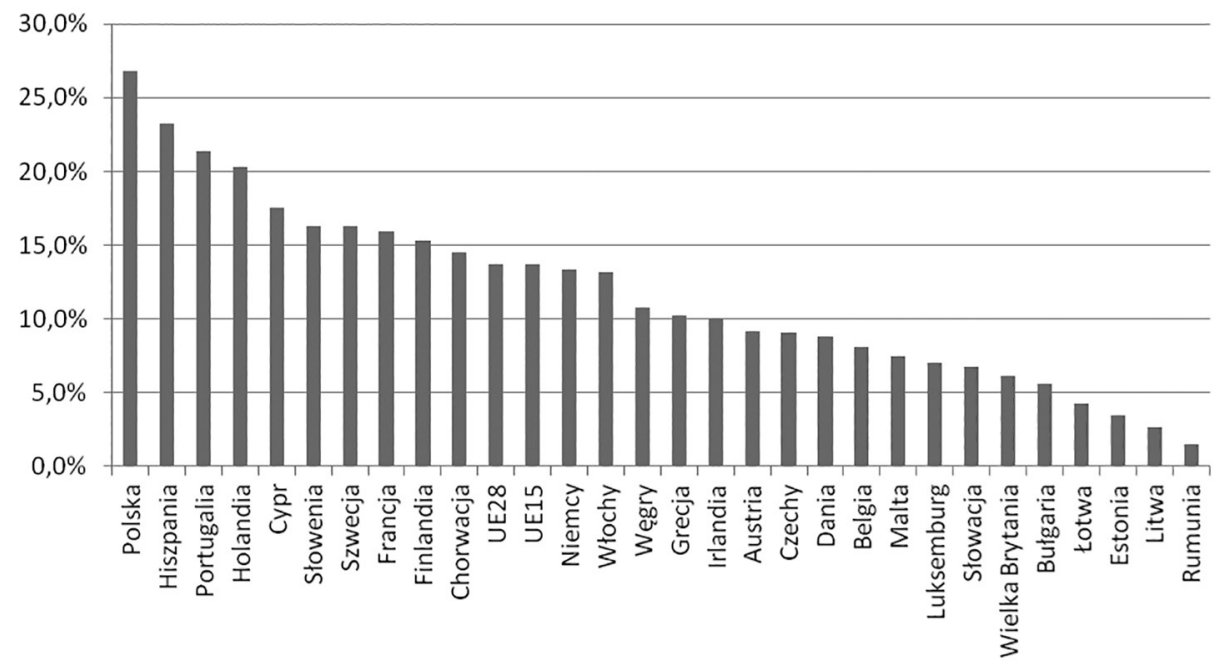

Rysunek 1. Udział pracowników na umowach terminowych w ogóle pracujących w 2013 r.

Źródło: Labour Force Survey, Eurostat.

Udział zatrudnionych na podstawie umów terminowych wśród pracujących w Polsce niemal dwukrotnie przekracza średnią dla krajów starej unijnej piętnastki (13,7\%). W Niemczech wynosi nieco ponad 13\%, zaś u obu naszych południowych sąsiadów nie przekracza 10\%. Prześledzenie trendów dotyczących skali tego zjawiska w ostatnich kilkunastu latach ujawnia bardzo szybki wzrost popularności umów 
terminowych w Polsce - ich udział wśród pracowników wzrósł z poziomu zaledwie 6\% w 2000 r. do $25 \%$ już w 2005 r. - przy stabilnej wartości tego odsetka przeciętnie w Unii Europejskiej (wzrost w tym samym okresie z 12 do 15\%, od 2008 r. spadek do 14\%). Wcześniej krajem o największym udziale tego typu umów była Hiszpania, doświadczająca poważnych trudności ekonomicznych i bardzo dużej skali bezrobocia, która jednak zdołała obniżyć o kilka punktów procentowych wartość omawianego wskaźnika. Tymczasem od 2006 r. odsetek pracujących na podstawie umów czasowych w Polsce utrzymuje się na niemal niezmienionym poziomie.

Drugą istotną formą zatrudnienia niosącą znaczny wzrost elastyczności w rozpatrywanych tu wymiarach jest samozatrudnienie. Praca na własny rachunek to zgodnie z obowiązującymi przepisami forma aktywności zawodowej, w której nie powinien występować nadzór przełożonego, ustalone przez zleceniodawcę miejsce i czas świadczenia pracy, zaś osoba ją wykonująca sama odpowiada za rezultaty swojej działalności wobec osób trzecich i ponosi ryzyko gospodarcze ${ }^{10}$. Ta forma zatrudnienia wymaga więc określonych dyspozycji, w tym umiejętności samodzielnego organizowania sobie czasu pracy oraz radzenia sobie z rodzajami ryzyka specyficznymi dla prowadzenia działalności gospodarczej. Zgodnie z danymi Labour Force Survey Polska należy do czołówki państw UE pod względem udziału osób pracujących na własny rachunek wśród ogółu pracujących, z wynikiem 14\%. Dane za 2013 r. przedstawiono na rysunku 2.

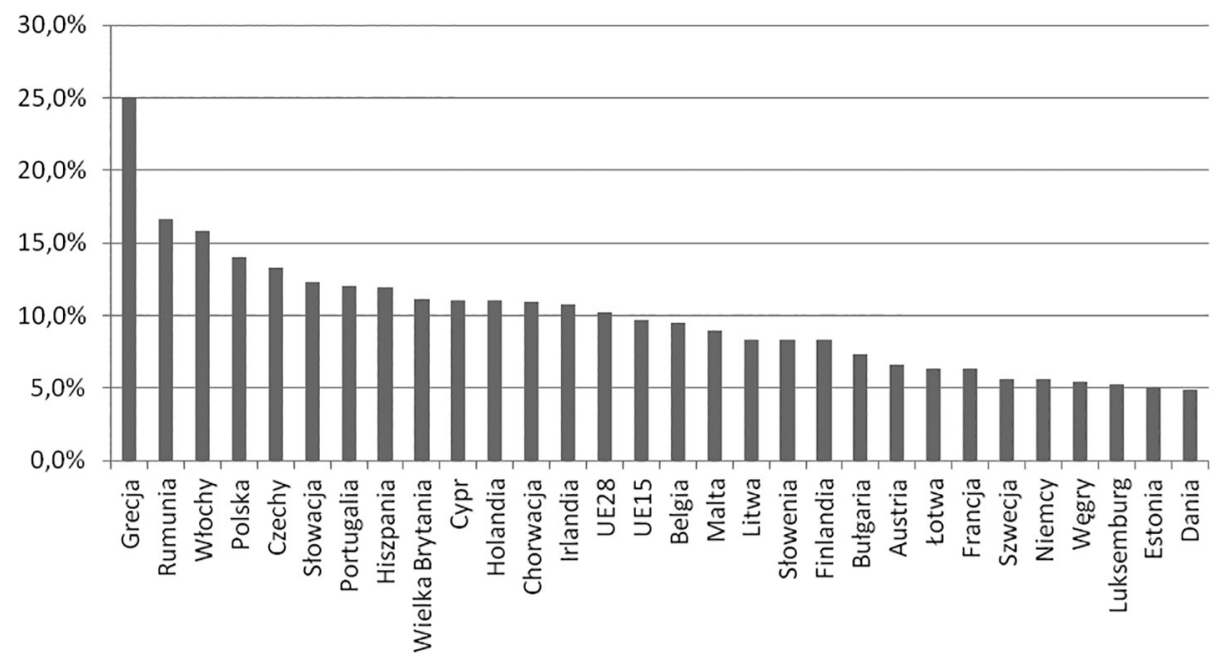

Rysunek 2. Udział osób samozatrudnionych w ogóle pracujących w 2013 r.

Źródło: Labour Force Survey, Eurostat.

10 Zob. Ustawa z dnia 26 lipca 1991 r. o podatku dochodowym od osób fizycznych, Dz. U. 1991, nr 80, poz. 350 , art. 5 b, ust. 1 . 
Wśród państw z dużym odsetkiem osób samozatrudnionych przeważają te, które doświadczają poważnych problemów ekonomicznych lub są nowymi członkami UE. Najwięcej pracujących na własny rachunek notuje się w Grecji - stanowią aż jedną czwartą pracujących. Wysoki poziom tego wskaźnika charakteryzuje również Rumunię, Włochy, Czechy, Słowację, Portugalię i Hiszpanię - dopiero za tymi krajami lokuje się liberalna gospodarczo Wielka Brytania. Wśród państw o niskim (mniej niż 10\%) udziale samozatrudnionych silnie zaznacza się obecność krajów o konserwatywnym i skandynawskim modelu polityki społecznej.

Podobnie jak samozatrudnienie, również umowy cywilnoprawne stanowią niepracowniczą formę zatrudnienia, regulowaną przepisami innymi niż Kodeks pracy. Ich podstawę prawną stanowi Kodeks cywilny. Obowiązki pracodawcy (zleceniodawcy) względem pracownika (zleceniobiorcy) najbardziej zredukowane są w wypadku umowy o dzieło. Jest ona określana jako umowa rezultatu: pracownik zobowiązuje się do dostarczenia określonego produktu (dzieła), i to w jego gestii leżeć powinno, w jaki sposób będzie wyglądał proces wykonania dzieła. Zawarcie umowy o dzieło nie podlega obowiązkowemu ani dobrowolnemu ubezpieczeniu zdrowotnemu lub emerytalno-rentowemu. Inaczej jest w wypadku drugiego rodzaju umowy cywilnoprawnej - umowy zlecenia. To rozwiązanie prawne, określane jako umowa starannego działania (podstawę wynagrodzenia stanowi sam proces świadczenia pracy, nadal jednak bez nadzoru przełożonego oraz przy samodzielnym organizowaniu czasu i miejsca pracy przez wykonującą ją osobę - w przeciwnym razie spełnione są warunki nawiązania stosunku pracy) podlega obowiązkowemu ubezpieczeniu zdrowotnemu, a także emerytalno-rentowemu, jeżeli dana umowa zlecenia stanowi jedyne źródło dochodu pracownika ${ }^{11}$. W przeciwnym razie (umowa o pracę z innym pracodawcą, wykonywanie więcej niż jednego zlecenia) ubezpieczenie społeczne jest jedynie dobrowolne.

W statystyce publicznej brak jest systematycznych danych dotyczących skali wykorzystania umów cywilnoprawnych. Szczególnie trudny jest do oszacowania odsetek osób świadczących pracę wyłącznie na podstawie umów cywilnoprawnych w danej jednostce sprawozdawczej, np. w ciągu roku. Wskaźnik ten stanowiłby cenne źródło wiedzy na temat skali popularności zatrudniania pracowników zupełnie pozbawionych ochrony wynikającej z Kodeksu pracy. W 2012 r. Główny Urząd Statystyczny udostępnił szacunki, zgodnie z którymi w roku tym 1,35 mln pracujących w Polsce miało podpisaną wyłącznie umowę cywilnoprawną. Próbując uzyskać przybliżone dane dotyczące popularności tej formy zatrudnienia, można śledzić dane Zakładu

${ }^{11}$ Składka odprowadzana jest również, jeżeli pracownik wykonuje dodatkowe zlecenie na rzecz swojego pracodawcy, z którym ma zawartą umowę o pracę. 
Ubezpieczeń Społecznych dotyczące liczby osób podlegających ubezpieczeniu społecznemu z tytułu zawarcia umowy cywilnoprawnej ${ }^{12}$. Dostępne są jednak tylko dane kwartalne, które w dodatku nie wskazują ściśle liczby osób pracujących wyłącznie na podstawie takiego rodzaju umowy - nawet jeśli zgodnie z intuicją założyć, że bardzo niewiele jest osób decydujących się na odprowadzenie składki na ubezpieczenie społeczne, gdy nie jest to obowiązkiem. Zgodnie z najnowszymi dostępnymi danymi, w drugim kwartale 2014 r. było 935 tys. osób ubezpieczonych społecznie z tytułu zawarcia umowy cywilnoprawnej.

W wypadku pracy tymczasowej dostępne są ścisłe dane dotyczące skali jej stosowania. Jest to forma zatrudnienia regulowana odrębną ustawą ${ }^{13}$, polegająca na udostępnianiu pracodawcom pracowników przez agencje pracy tymczasowej. W większości wypadków rozwiązanie to służy dorywczemu uzupełnianiu personelu firmy, np. w okresie urlopowym lub w razie nieprzewidzianego wzrostu zamówień. $\mathrm{Na}$ ogół rekrutowani są w ten sposób pracownicy o niskich kwalifikacjach, do prostych zadań niewymagających długotrwałego przysposobienia. Zgodnie z danymi MPiPS, od 2004 do 2013 r. liczba pracowników tymczasowych wzrosła ze 168 tys. do 559 tys., zaś przedsiębiorstw korzystających z ich pracy z 1558 do 13 993. Był to więc bardzo dynamiczny wzrost. Obecnie Polska jest trzecim pod względem wielkości rynkiem agencji pracy tymczasowej w UE, a nadal przewiduje się jego rozwój ${ }^{14}$.

\section{Przyczyny popularności elastycznych form zatrudnienia w Polsce}

Warte rozważenia jest, $\mathrm{z}$ jakich powodów pracodawcy w Polsce intensywnie wykorzystują umowy terminowe oraz formy zatrudnienia o charakterze niepracowniczym, mimo że na tle innych państw europejskich rozwiązywanie bezterminowej umowy o pracę nie podlega szczególnie ścisłym restrykcjom. Istnieje przynajmniej kilka hipotez, które wyjaśniają to zjawisko.

Jedną z prawdopodobnych przyczyn może być silna asymetryczność rynku pracy w Polsce. „Efektem ubocznym” przyjętego modelu transformacji ustrojowej był,

${ }_{12}$ M. Trawińska, Minimum wage data shocks experts, raport sporządzony dla Europejskiej Fundacji na rzecz Poprawy Warunków Życia i Pracy (Eurofound), http://eurofound.europa.eu/observatories/eurwork/articles/working-conditions/minimum-wage-data-shocks-experts, dostęp 23.03.2015.

13 Ustawa z dnia 9 lipca 2003 r. o zatrudnianiu pracowników tymczasowych, Dz. U. 2003, nr 166, poz. 1608 .

14 Materiały na konferencję 10 lat pracy tymczasowej w Polsce 29 września 2014 r., http://okap.org. pl/files/10083952100822082014093010_LAT_PRACY_TYMCZASOWEJ_W_POLSCE_Prezentacja.pdf, dostęp 23.03.2015. 
i w dalszym ciągu jest, wysoki poziom bezrobocia, którego stopa przez dużą część ostatniego ćwierćwiecza osiągała wartość dwucyfrową ${ }^{15}$. Sprawia to, że w zakresie indywidualnych stosunków pracy strona popytowa rynku pracy posiada znaczną przewagę negocjacyjną, mogąc narzucać korzystne dla siebie warunki, na jakich zawierane są umowy. Pracownicy muszą godzić się na nie, gdyż w sytuacji niedoboru miejsc pracy odrzucenie proponowanego przez pracodawcę kształtu umowy oznacza bezrobocie. Warto zauważyć, że do bardzo gwałtownego wzrostu odsetka osób zatrudnianych na umowach terminowych doszło w latach 2000-2005, kiedy notowano bardzo wysoki, przez pewien czas przekraczający $20 \%$ poziom bezrobocia rejestrowanego ${ }^{16}$.

W powyższej sytuacji interesów pracowników nie mogą dostatecznie chronić związki zawodowe. Ich pozycja w Polsce jest relatywnie słaba na tle innych państw $\mathrm{UE}^{17}$. Należy do nich niewielki odsetek pracujących. Ponadto niewielkie i wciąż malejące znaczenie mają układy zbiorowe pracy $^{18}$. Jest to konsekwencją nie tylko deficytu miejsc pracy i niedopasowania struktury kwalifikacji pracobiorców do zapotrzebowania na nie w szybko restrukturyzującej się gospodarce, ale również określonego modelu prywatyzacji. Zakładał on zapewnienie dużej swobody w zakresie zarządzania zasobami ludzkimi zagranicznym inwestorom ${ }^{19}$ - intensywny napływ obcego kapitału, mimo że sprzyjał tworzeniu miejsc pracy, nie zawsze korzystnie wpływał na ich jakość.

To sprawiło, że w Polsce ukształtowała się gospodarka rynkowa, której bliżej do modelu liberalnego (występującego m.in. w państwach anglosaskich) niż koordynowanego (kształtującego stosunki pracy na przykład w Niemczech), zgodnie ze szkołą różnorodności kapitalizmu ${ }^{20}$. Wreszcie obecna skala wykorzystania różnych elastycznych form zatrudnienia to również skutek kształtu przepisów Kodeksu pracy i innych ustaw regulujących zawieranie umów na rynku pracy, praktyki ich stosowania przez pracodawców, orzecznictwa sądów pracy oraz skuteczności państwowych urzędów kontrolujących legalność zatrudnienia i zasadność użycia określonych rozwiązań prawnych jemu towarzyszących.

${ }_{15}$ T. Kowalik, www.polskatransformacja.pl, Wydawnictwo MUZA, Warszawa 2009.

16 Dane historyczne GUS, http://stat.gov.pl/obszary-tematyczne/rynek-pracy/bezrobocie-rejestrowane/stopa-bezrobocia-w-latach-1990-2015,4,1.html, dostęp 23.03.2015.

17 Trade union membership 2003-2008, Eurofound, Dublin 2009, http://eurofound.europa.eu/sites/default/files/ef_files/docs/eiro/tn0904019s/tn0904019s.pdf, dostęp 23.03.2015.

$18 \mathrm{~J}$. Czarzasty, Rola układów zbiorowych pracy w Polsce, raport sporządzony dla Eurofound, https:// eurofound.europa.eu/sites/default/files/ef_files/eiro/2002/10/feature/pl0210108fpl.doc, dostęp 23.03.2015.

${ }_{19}$ R. Woś, Dziecięca choroba liberalizmu, Wydawnictwo Studio Emka, Warszawa 2014.

20 J. Gardawski, Korporacje transnarodowe a Europejskie Rady Zakładowe w Polsce, Oficyna Wydawnicza SGH, Warszawa 2007. 


\section{Regulacje prawne i polityka państwa dotycząca elastycznych form zatrudnienia}

W Polsce deklaruje się prowadzenie rekomendowanej przez Unię Europejską polityki zapewniania bezpieczeństwa zatrudnienia w warunkach elastyczności rynku pracy $^{21}$. W praktyce jednak mechanizmy mające zapewniać minimum bezpieczeństwa socjalnego i wsparcie dla osób tracących zatrudnienie okazują się zawodne. Wątpliwości budzić może kształt krajowych regulacji dotyczących form zatrudnienia, praktyka ich stosowania oraz skuteczność organów państwa w zakresie egzekwowania tych przepisów.

Większość rządów od początku lat 90. realizowało w Polsce politykę rynku pracy, która służyć miała uelastycznieniu zatrudnienia. Jednocześnie można odnieść wrażenie, że nie przywiązywano należytej wagi do tworzenia spójnych i przejrzystych przepisów regulujących zawieranie umów między pracodawcami i pracownikami, dostatecznie chroniących przed nadużyciami w stosowaniu umów terminowych ${ }^{22}$. Pierwszym etapem realizowanych $\mathrm{w}$ duchu neoliberalizmu reform były zmiany w zakresie zbiorowych stosunków pracy i konstrukcji systemu zabezpieczenia społecznego, które przypadły na lata $90^{23}$. Do największych zmian w sferze indywidualnych stosunków pracy doszło w następnej dekadzie - należy wskazać tu przede wszystkim nowelizację Kodeksu pracy z 2002 r., która między innymi zniosła limit odnowień umowy o pracę na czas określony. Liberalizację prawa pracy uzasadniano potrzebą uelastycznienia rynku pracy, mającego sprzyjać zwalczaniu bezrobocia ${ }^{24}$. Część przepisów chroniących przed nadużyciami w stosowaniu umów czasowych trzeba było zresztą wkrótce potem przywrócić w związku ze wstąpieniem naszego państwa do UE.

Polska zobowiązana jest do zapewnienia ochrony pracowników atypowych przed dyskryminacją. Powinna także wprowadzać skuteczne mechanizmy zapobiegające nadużyciom w stosowaniu elastycznych form zatrudnienia. Wynika to m.in. z jej członkostwa w Międzynarodowej Organizacji Pracy i UE. Należy w tym miejscu

${ }^{21}$ Wspólne zasady wdrażania modelu flexicurity, Komunikat Komisji do Parlamentu Europejskiego, Rady, Europejskiego Komitetu Ekonomiczno-Społecznego i Komitetu Regionów, Bruksela 2007, www.mpips. gov.pl/userfiles/File/flexi_komunikat_ue.pdf, dostęp 23.03.2015.

22 Należy jednak zaznaczyć, że starano się zapewnić ochronę przed zawieraniem umów cywilnoprawnych w sytuacji istnienia przesłanek nawiązania stosunku pracy, czemu służyła już nowelizacja Kodeksu pracy z 1996 r., zob. J. Wratny, Nietypowe formy zatrudnienia w perspektywie polskiego prawa pracy, w: Deregulacja polskiego rynku pracy, red. K.W. Frieske, Warszawa 2003, IPiSS, s. 118-129.

${ }_{23}$ J. Grzegorczyk, Koniec etatu?, „Obywatel” 2010, nr 2, s. 89-94.

${ }^{24}$ J. Winczorek, Regulacja rynku pracy a bezrobocie - uwagi metodologiczne, w: Deregulacja polskiego..., op.cit., s. 173-195. 
przede wszystkim wymienić Dyrektywę 1999/70/WE w sprawie pracy na czas określony oraz Dyrektywę 2008/104/WE w sprawie pracy tymczasowej.

Dokumenty te zobowiązują państwa członkowskie UE do zapewnienia równego traktowania pracowników stałych i czasowych - warunki zatrudniania tych drugich nie mogą być gorsze tylko dlatego, że pracują oni na podstawie umowy o pracę na czas określony, uzasadniać mogą je jedynie inne okoliczności - oraz wprowadzenia mechanizmów, które uniemożliwią nieuzasadnione stosowanie umów czasowych. Konstrukcja niektórych przepisów Kodeksu pracy uniemożliwia skuteczne realizowanie tych celów. Po pierwsze, przepisy wymagają uzasadnienia przez pracodawcę wypowiedzenia umowy tylko $\mathrm{w}$ wypadku zatrudnienia na czas nieokreślony. Już to stwarza nierówność warunków zatrudnienia - defaworyzowane są w ten sposób osoby pracujące na podstawie umów terminowych ${ }^{25}$. Dyrektywa zobowiązuje państwa członkowskie do przyjęcia skutecznych sposobów ograniczania nadużyć w stosowaniu umów czasowych i sprzyjających wykorzystywaniu ich jedynie w uzasadnionych wypadkach. Można w tym celu wybrać dowolne spośród następujących obostrzeń: - umożliwienie użycia tej formy zatrudnienia w obiektywnie uzasadnionych wypadkach (ze względu na charakter świadczonej pracy),

- ograniczenie liczby odnowień tego rodzaju umów przez pracodawcę z jednym pracownikiem,

- $\quad$ wyznaczenie maksymalnej łącznej długości kolejnych okresów umów.

Przykładowo, w Niemczech zdecydowano się na wykorzystanie wszystkich trzech rodzajów restrykcji. Jeżeli brak jest obiektywnych powodów do wykorzystania umowy terminowej, maksymalny czas jej trwania wynosi 24 miesiące (48 miesięcy dla nowych firm oraz zatrudniania pracowników powyżej 52. r.ż.). Możliwe są maksymalnie cztery odnowienia umowy.

W Polsce przyjęto dopuszczalność umowy o pracę na czas określony w razie istnienia obiektywnych przyczyn do jej zawarcia. W pozostałych wypadkach możliwe są maksymalnie dwa odnowienia - trzecie skutkuje zawarciem umowy na czas nieokreślony ${ }^{26}$. Jest to ograniczenie łatwe do obejścia poprzez krótkookresowe zatrudnienie pracownika na podstawie umowy cywilnoprawnej ${ }^{27}$, które ponadto w żaden sposób nie chroni przed możliwością zawierania wieloletnich kontraktów tego typu. Z bogatego

${ }^{25}$ K. Łapiński, Umowa o prace na czas określony w polskim i unijnym prawie pracy, Lex a Wolters Kluwer business, Warszawa 2011.

${ }^{26} \mathrm{~W}$ okresie obowiązywania tzw. ustawy antykryzysowej (Ustawa z dnia 1 lipca 2009 r. o łagodzeniu skutków kryzysu ekonomicznego dla pracowników i przedsiębiorców, Dz. U. 2009, nr 125, poz. 1035) obowiązywało ograniczenie czasu trwania umowy z pracownikiem do 24 miesięcy. Było to jednak rozwiązanie przejściowe, które nie przyczyniło się do zmniejszenia skali wykorzystania tego rodzaju umów w Polsce.

27 Ibidem, s. 263. 
orzecznictwa Sądu Najwyższego dotyczącego tej kwestii wynika, że zawieranie wieloletnich umów o pracę na czas określony nie powinno być stosowane. Może bowiem służyć obchodzeniu przepisów prawa pracy i ich społeczno-gospodarczego przeznaczenia, a także łamać zasady współżycia społecznego ${ }^{28}$. Dotyczy to szczególnie przypadków, dopuszczanych przez Kodeks pracy, zawierania takiej umowy z klauzulą o możliwości jej rozwiązania z dwutygodniowym wypowiedzeniem.

Zdaniem specjalistów prawa pracy dopuszczalność takiego wypowiedzenia w wypadku umów zawieranych na co najmniej sześć miesięcy stanowi wypaczenie pierwotnych założeń ustawodawcy, zgodnie z którymi umowa o pracę na czas określony powinna być rozwiązaniem istotnie stabilizującym zatrudnienie (pomimo jego stosunkowo krótkiego horyzontu czasowego ${ }^{29}$. Możliwość wcześniejszego wypowiedzenia takiej umowy została zapewniona na wypadek zaistnienia okoliczności nieprzewidzianych przez strony w momencie jej zawierania. Tymczasem stało się to rozwiązaniem powszechnym i w istotnym stopniu ograniczającym prawa pracownicze, o czym będzie mowa w następnej części tego artykułu. Dodatkowo, jeszcze w pierwszej połowie lat 90., Sąd Najwyższy w uchwale dopuścił możliwość rozwiązania takiej umowy nawet przed upływem pierwszych sześciu miesięcy jej trwania, co dodatkowo osłabia jej stabilizujący wpływ na sytuację pracownika ${ }^{30}$.

W odniesieniu do praktyki stosowania wieloletnich umów o pracę na czas określony SN, chociaż wskazuje na ich potencjalną sprzeczność z założeniami, na jakich powinno się opierać zatrudnienie terminowe, zajmował raczej permisywne stanowisko. Uznał, iż nie jest możliwe wskazanie maksymalnego okresu trwania umów na czas określony $^{31}$. Orzekł również, że sądy pracy powinny respektować wolę stron, jeżeli do zawarcia takiej wieloletniej umowy doszło ${ }^{32}$. Jest to o tyle problematyczne, że w warunkach wysoce asymetrycznego polskiego rynku pracy typ zawieranej umowy często wynika jedynie z woli strony zatrudniającej. Pracownik z dużym prawdopodobieństwem zaakceptuje proponowane warunki, gdyż jedyną opcją alternatywną jest dla niego bezrobocie. Zarówno legislacja, jak i wykładnia prawa pracy stworzyły więc okoliczności umożliwiające powszechne stosowanie umów terminowych, nawet w razie ich wątpliwej zasadności.

${ }^{28}$ Wyrok SN z dnia 7 września 2005 r., II PK 294/04, wyrok SN z dnia 25 października 2007 r., II PK 49/07.

${ }^{29}$ E. Suknarowska-Drzewiecka, Długoterminowa umowa o pracę na czas określony, „Monitor Prawa Pracy" 2010, nr 5, s. 242-245.

${ }^{30}$ Uchwała SN z dnia 7 września 1994 r., I PZP 35/94.

${ }^{31}$ Ibidem.

32 Wyrok SN z dnia 30 września 2009 r., II PK 88/09. 
Dyrektywę w sprawie pracy tymczasowej zaimplementowano w polskim prawie poprzez uchwalenie odrębnej ustawy ${ }^{33}$. Zapewnia ona pracownikom tymczasowym wiele praw ochronnych, służących zrównaniu ich warunków zatrudnienia z warunkami, na jakich świadczy pracę wewnętrzny personel przedsiębiorstwa - w tym stawek wynagrodzenia zgodnych $\mathrm{z}$ obowiązującą siatką płac. Istotny jest zapis uniemożliwiający agencji zobowiązanie pracodawcy, że nie zatrudni on pracownika tymczasowego na umowie stałej. W kwestiach nieuregulowanych (a tych jest stosunkowo niewiele; m.in. określono dokładnie obowiązki agencji pracy tymczasowej i pracodawcy użytkownika czy wymiar przysługujących urlopów) ustawa odsyła do Kodeksu pracy. Praca tymczasowa ma być więc formą zatrudnienia, która - pomimo $\mathrm{z}$ reguły niskich wynagrodzeń oraz niewielkiego faktycznego wymiaru czasu pracy - zapewnia podstawy bezpieczeństwa socjalnego, ogranicza ryzyko dyskryminacji i może stanowić efektywny kanał rekrutacji na wewnętrzne stanowiska pracy w firmach. Jednakże konstrukcja artykułu 26 ustawy sprawia, że dla dużej części pracowników tymczasowych wskazanych wyżej przepisów ochronnych się nie stosuje. W ustępie pierwszym tego artykułu ustawodawca wskazuje możliwość zatrudniania uczących się osób w wieku od 16 do 18 lat na podstawie umowy cywilnoprawnej. W ustępie drugim wymieniono artykuły ustawy, które stosuje się w takiej sytuacji - nie wspomniano jednak ponownie o kategorii wiekowej wskazanej w ustępie pierwszym. To sprawia, że powszechnie uznaje się dopuszczalność zatrudniania pracowników tymczasowych, bez względu na ich wiek, na podstawie umowy cywilnoprawnej - w takiej sytuacji zasada równego traktowania i ochrona kodeksowa traci zupełnie moc. W $2013 \mathrm{r}$. spośród 559 tys. pracowników tymczasowych aż 319 tys. (57\%) zatrudnianych było w ten sposób ${ }^{34}$, mimo uchwały SN z 2011 r., z której wynika, że jeżeli charakter zadań wykonywanych przez pracownika tymczasowego stwarza przesłanki do nawiązania stosunku pracy, powinna zostać z nim zawarta umowa o pracę ${ }^{35}$.

Osobnym problemem jest zjawisko stosowania umów cywilnoprawnych lub nawiązywania współpracy z osobą pracującą na własny rachunek, gdy spełnione są przesłanki nawiązania stosunku pracy. Obowiązujące w Polsce przepisy, w tym art. 22 Kodeksu pracy, stwarzają podstawę do identyfikacji takich sytuacji. Państwowa Inspekcja Pracy w ostatnich latach zwraca na ten problem szczególną uwagę w trakcie planowych kontroli legalności zatrudnienia, a także w reakcji na skargi

${ }^{33}$ Ustawa z dnia 9 lipca 2003 r. o zatrudnianiu pracowników tymczasowych, Dz. U. 2003, nr 166, poz. 1608.

${ }^{34}$ Dane MPiPS.

${ }^{35}$ Uchwała z dnia 12 grudnia 2011 r., sygn. I UZP 6/11. Dokładne omówienie problemu zob. A. Reda, Praca tymczasowa na podstawie umowy cywilnoprawnej, „Praca i Zabezpieczenie Społeczne 2012” 2011, nr 9, s. 33-38. 
spływające do tej instytucji. Zdaniem autorów raportu Głównego Inspektora Pracy, nasiliło się zjawisko zatrudniania na podstawie umowy cywilnoprawnej w warunkach wskazujących na istnienie stosunku pracy w 2013 r. Wskazują oni, że może wynikać to z pogarszającej się sytuacji na rynku pracy (ponownie alternatywą dla takiej formy zatrudnienia jest bezrobocie), jak również trudności samych firm, próbujących redukować koszty zatrudnienia ${ }^{36}$. Umowy cywilnoprawne stosują zwłaszcza małe przedsiębiorstwa, szczególnie w branży budowlanej, handlowej oraz w przetwórstwie przemysłowym. Chociaż należy mieć na względzie to, że dane te nie mają charakteru reprezentatywnego dla wszystkich polskich firm, niepokoić może skala wykorzystania umów niepracowniczych w 501 skontrolowanych podmiotach: zatrudniały one 69,5 tys. osób na podstawie umowy o pracę i aż 149 tys. na podstawie umowy cywilnoprawnej. Dodatkowo, 1,3 tys. ich pracowników realizowało swoje zadania, prowadząc działalność gospodarczą.

Oznacza to, że istnieje znacząca grupa firm, w których zatrudnienie pracownicze jest rzadsze niż świadczenia pracy na podstawie innych form zatrudnienia. Również wyniki kontroli planowych PIP wskazują na skalę zjawiska: spośród 9 tys. firm w 19,7\% nie przestrzegano zakazu zawierania umów cywilnoprawnych w warunkach właściwych dla umowy o pracę. Problemem występującym na mniejszą skalę - jak wynika z wyżej zaprezentowanych danych - jest samozatrudnienie w analogicznej sytuacji podlegania przełożonemu i świadczenia pracy w określonym reżimie narzucanym przez pracodawcę ${ }^{37}$. Nawet jeżeli popularność tego zjawiska jest niższa - niewątpliwie trudniej nakłonić pracownika do podjęcia samodzielnej działalności gospodarczej niż zaproponować mu umowę zlecenia - ryzyko, jakiemu podlega taki pracownik należy ocenić jako większe. Musi on odprowadzać składki na obowiązkowe ubezpieczenia i zaliczki na podatek dochodowy, samodzielnie poruszając się po meandrach przepisów gospodarczych bądź ponosząc dodatkowe koszty usług księgowych.

\section{Społeczne i gospodarcze skutki stosowania elastycznych form zatrudnienia}

W niniejszym artykule zasadniczo pomijam ewentualne korzyści, jakie - najczęściej wykwalifikowani - pracownicy osiągają dzięki wykorzystaniu różnego rodzaju elastycznych rozwiązań organizacyjnych, zapewniających im większą swobodę w zakresie

\footnotetext{
${ }^{36}$ Sprawozdanie z działalności Państwowej Inspekcji Pracy w 2013 r., Główny Inspektorat Pracy, Warszawa 2014, s. 53-58.

37 E. Zarzycka, Polak elastyczny, „Tygodnik Solidarność” 2008, nr 34, s. 12.
} 
czasu, miejsca lub sposobu świadczenia pracy. Jako wybrany przykład pozytywnych następstw tego rodzaju elastyczności można wymienić większą łatwość w godzeniu aktywności zawodowej z innymi dziedzinami życia pracownika (work-life balance) ${ }^{38}$.

Elastyczność w rozpatrywanych w niniejszym artykule postaciach prowadzi jednak głównie do negatywnych dla pracowników skutków. Brak trwałości zatrudnienia wzmacnia niepewność rozwoju zawodowego, a także podnosi ryzyko utraty części lub całości praw socjalnych. Problem ten szeroko analizowano w literaturze zagranicznej. Jako przykłady ważnych opracowań poświęconych ekspansji elastycznych form zatrudnienia można wskazać prace R. Sennetta ${ }^{39}$ i G. Standinga ${ }^{40}$. Pierwszy z tych autorów podkreśla wpływ coraz większej niepewności towarzyszącej zatrudnieniu na psychikę pracowników, podczas gdy drugi ujmuje problem w kategoriach zmian w strukturze społecznej. Sugeruje powstawanie nowej klasy społecznej, prekariatu, złożonej z pracowników zatrudnianych na podstawie umów czasowych, przy zadaniach niewymagających wysokich kwalifikacji, nierzadko o charakterze dorywczym. Warunki ich zatrudnienia wiążą się z brakiem zabezpieczenia społecznego, z którego korzystać mogą przedstawiciele salariatu - pracownicy zatrudniani na podstawie standardowych, stabilnych umów.

W odniesieniu do wpływu zatrudnienia elastycznego na sytuację pracowników w Polsce warto przytoczyć wyniki analizy A. Kiersztyn, która na podstawie danych z polskiej edycji badań EU-SILC wykazała, że świadczenie pracy oparte na umowie na czas określony pociąga za sobą przeciętnie o kilkanaście procent niższe wynagrodzenia niż zatrudnienie stałe, i to przy uwzględnieniu innych cech pracowników istotnie wpływających na wysokość płac ${ }^{41}$. Praca na czas określony pociąga za sobą większe ryzyko ubóstwa, szczególnie dla osób będących członkami gospodarstw domowych, w których nikt nie jest zatrudniony na podstawie umowy bezterminowej.

Dodatkowo pracownicy na kontraktach czasowych zagrożeni są popadaniem $\mathrm{w}$ rotację między okresami pracy a bezrobociem. Ma to miejsce na skutek tendencji do zawierania kolejnych umów na czas określony, przy niewielkich szansach na uzyskanie stabilnego zatrudnienia. Oznacza to potwierdzenie hipotezy, zgodnie z którą rynek pracy w Polsce podlega silnej segmentacji, zaś przejście z segmentu brzegowego (obejmującego stanowiska z niekorzystnymi warunkami zatrudnienia) do segmentu

${ }^{38}$ Zob. np. J. Olszewski, System pracy w warunkach globalnego społeczeństwa informacyjnego, Wydawnictwo Uniwersytetu Ekonomicznego w Poznaniu, Poznań 2013.

${ }^{39}$ R. Sennett, Korozja charakteru. Osobiste konsekwencje pracy w nowym kapitalizmie, Wydawnictwo Literackie MUZA SA., Warszawa 2007.

${ }^{40}$ G. Standing, op.cit.

${ }^{41}$ A. Kiersztyn, Analiza ekonomicznych konsekwencji zatrudnienia na czas określony dla jednostek i gospodarstw domowych, w: Zatrudnienie na czas określony..., op.cit., s. 93-117. 
rdzeniowego (złożonego ze stanowisk oferujących lepsze, przede wszystkim stabilne warunki zatrudnienia) jest trudne ${ }^{42}$.

Zarazem podaje to w wątpliwość teorię przejściowych rynków pracy, sugerującą możliwość nawet wielokrotnego przechodzenia jednostki między obydwoma segmentami, w związku z następstwem kolejnych faz jej kariery zawodowej. Zatrudniani na czas określony mają powody, by czuć się pracownikami drugiej kategorii - to oni pierwsi są zwalniani w razie wystąpienia potrzeby redukcji personelu przez firmę ${ }^{43}$. To z kolei wpływa na mniejszą identyfikację z przedsiębiorstwem, lojalność wobec niego, a przez to może przekładać się również na niższą wydajność pracy. Pracujący na podstawie umów terminowych są również mniej zintegrowani z załogą, a przez to rzadziej skłonni do włączania się w organizacje związkowe, co stanowi jeden z czynników słabości dialogu społecznego w Polsce. Dodatkowo na brak zaangażowania w działalność związkową w niektórych wypadkach wpływać może mniej lub bardziej jawne grożenie przez pracodawcę nieodnowieniem umowy terminowej $\mathrm{w}$ razie przystąpienia do organizacji ${ }^{44}$.

Praca w gorszym segmencie oznacza niższe wynagrodzenie $e^{45}$, a także brak dodatkowych uprawnień płacowych wynikających ze stażu oraz możliwości awansu ${ }^{46}$. Ma to dodatkowe poważne konsekwencje makrospołeczne i makroekonomiczne. To choćby jeden z czynników opóźniających usamodzielnienie się osób młodych w Polsce, szczególnie często pracujących na czas określony (w 2013 r. pracowało tak w Polsce $68,6 \%$ osób w wieku od 15 do 24 lat, przy średniej UE na poziomie $42,5 \%)^{47}$. Może to opóźniać wyprowadzenie się młodych z rodzinnego domu, założenie rodziny i decyzje prokreacyjne. Przekłada się to następnie na pogorszenie sytuacji demograficznej.

Osoby bez stabilnego zatrudnienia mają utrudniony dostęp do kredytów hipotecznych. Czasami problem rozwiązywany jest poprzez wykorzystanie zdolności kredytowej członka rodziny, który ma umowę na czas nieokreślony ${ }^{48}$. Jednak to z kolei wzmacnia i tak obecny w Polsce familizm, rozumiany jako cecha modelu polityki społecznej polegająca na deficycie skutecznych mechanizmów zabezpieczenia

${ }^{42}$ M. Bednarski, op.cit.

${ }^{43}$ E. Zarzycka, op.cit.

${ }^{44} \mathrm{~J}$. Wratny, Elastyczne formy zatrudnienia w perspektywie polskiego prawa pracy, w: Elastyczne formy pracy. Szanse i zagrożenia, red. C. Sadowska-Snarska, Wydawnictwo Wyższej Szkoły Ekonomicznej w Białymstoku, Białystok 2008, s. 24-33.

${ }^{45}$ A. Kiersztyn, op.cit.

${ }^{46}$ E. Zarzycka, op.cit.

${ }^{47}$ Dane Labour Force Survey, Eurostat.

${ }_{48} \mathrm{P}$. Teisseyre, Wplyw zatrudnienia na czas określony na szanse partycypacji na rynku nieruchomości, w: M. Bednarski, Zatrudnienie na czas określony..., op.cit., s. 192-204. Analizy statystyczne autora nie wykazały bezpośredniej zależności odraczania decyzji prokreacyjnych od zatrudnienia terminowego, choć sugerowały to niektóre wypowiedzi uczestników badania o charakterze jakościowym. 
społecznego oferowanych przez państwo; braki te muszą być uzupełniane przez rodzinę ${ }^{49}$. W jednym $\mathrm{z}$ badań odnotowano sytuację, w której przedstawiciel dużej firmy deklarował, że jest ona otwarta na renegocjację umowy o pracę (przedłużenie umowy na czas określony, ewentualnie zamianę na kontrakt bezterminowy), jeżeli pracownik potrzebuje wykazania zdolności kredytowej ${ }^{50}$. Trudno jednak ocenić, jak często może dochodzić do takich sytuacji; należy też oczekiwać, że na taką przychylność mogą liczyć jedynie pracownicy o stosunkowo silnej pozycji, wykwalifikowani, z którymi pracodawca wiąże plany dłuższej współpracy. Problemy z dostępem do kredytu hipotecznego w związku z dużą liczbą pracowników na umowach czasowych mogą również negatywnie wpływać na kondycję sektora budownictwa mieszkaniowego, obniżając popyt na nowe lokale.

Skutki pracy opartej na wcześniej opisywanych niepracowniczych formach zatrudnienia obejmują te będące następstwem stosowania różnych wariantów czasowej umowy o pracę oraz wiele innych następstw, przede wszystkim związanych z nieobowiązywaniem przepisów Kodeksu pracy ${ }^{51}$. Częstym powodem sięgania po niepracownicze rozwiązania prawne przez pracodawców jest obchodzenie norm związanych z czasem pracy oraz wymaganym odpoczynkiem w ciągu doby i tygodnia, respektowanych w wypadku istnienia stosunku pracy. Brak jest również płatnych urlopów wypoczynkowych, zaś koszty choroby przeniesione zostają na pracownika ${ }^{52}$. Nie obowiązuje wynagrodzenie minimalne. W dalszym ciągu osoby świadczące pracę na podstawie umów cywilnoprawnych i samozatrudnione nie dysponują także prawem zakładania lub przystępowania do związków zawodowych ${ }^{53}$, mimo stanowiska MOP (Międzynarodowej Organizacji Pracy), która w odpowiedzi na skargę NSZZ „Solidarność” wskazała, że prawo koalicji powinno zostać rozszerzone na te kategorie pracujących ${ }^{54}$.

Zatrudnienie niepracownicze niesie ze sobą również konsekwencje związane $\mathrm{z}$ niedostatecznym zabezpieczeniem przed ryzykiem socjalnym, wpływając też

49 Ibidem.

50 J. Konieczna-Sałamatin, M. Pańków, J. Stasiowski, Analiza struktury, uwarunkowań i perspektyw rozwoju alternatywnych form zatrudnienia na Dolnym Śląsku. Raport Końcowy, Dolnośląski Wojewódzki Urząd Pracy, Wałbrzych 2011, s. 94.

51 Należy pamiętać, że dla części pracujących takie formy zatrudnienia jak umowy cywilnoprawne czy praca na własny rachunek mogą być korzystne. Dotyczy to wykwalifikowanych pracowników, specjalistów, przedstawicieli wolnych zawodów czy artystów ceniących swobodę, elastyczną organizację czasu pracy oraz możliwość wykonywania zadań dla różnych zleceniodawców. Jednak nawet te osoby mogą odczuć w pewnych sytuacjach lub po upływie dłuższego czasu niektóre z opisywanych negatywnych skutków takich umów. Sposób, w jaki są zatrudnieni, niesie ze sobą również analizowane tu konsekwencje makroekonomiczne.

52 Sprawozdanie z działalności..., s. 56.

53 Ustawa z dnia 23 maja 1991 r. o związkach zawodowych, Dz. U. 1991, nr 55, poz. 234 z późn. zm.

54 Wnioski i zalecenia Komitetu Wolności Związkowej (Raport MOP z 313 sesji), www.solidarnosc. org.pl/images/files/dokumenty/eksperckie/mop/Raport_Komitetu_ds_Wolnoci_Zwiazkowych_MOP_ GB_313_INS_9.pdf, dostęp 30.03.2015. 
na sytuację finansową systemu ubezpieczeń społecznych. W największym stopniu dotyczy to pracujących na podstawie umowy o dzieło, od której nie są odprowadzane składki na ubezpieczenie zdrowotne ani społeczne. Sytuacja takich osób jest więc mniej korzystna niż bezrobotnych zarejestrowanych w Urzędzie Pracy, objętych z tego tytułu ubezpieczeniem zdrowotnym. W wypadku umowy zlecenia ten problem nie występuje, jednak obowiązek odprowadzania składek na ubezpieczenie emerytalno-rentowe zachodzi z tytułu tylko jednej z realizowanych w danym czasie umów, co prowadzi do częstego zaniżania kwoty wynagrodzenia i wypłaty jego reszty z tytułu innego kontraktu. Obniża to wysokość oszczędności emerytalnych pracownika, jak również powoduje zmniejszenie przychodów systemu ubezpieczeń społecznych ${ }^{55}$.

Dlatego uchwalona niedawno nowelizacja ustawy o ubezpieczeniach społecznych narzuca obowiązek odprowadzania składek od więcej niż jednej umowy, do momentu osiągnięcia w danym miesiącu kwoty minimalnego wynagrodzenia ${ }^{56}$. Spowoduje to wzrost wpływów Funduszu Ubezpieczeń Społecznych, jednak zmiana ta wejdzie w życie dopiero 1 stycznia 2016 r. Osobny problem stanowią zasady, na jakich odprowadzane są składki na obowiązkowe ubezpieczenia $\mathrm{z}$ tytułu pracy na własny rachunek. Ich minimalny wymiar w wypadku prowadzenia działalności gospodarczej dłużej niż 24 miesiące (jeśli jest to pierwsza założona firma, składki są niższe przez dwa lata) wynosi $60 \%$ prognozowanego miesięcznego wynagrodzenia w danym roku $^{57}$. Sprawia to, że mamy de facto do czynienia z „pogłównym” ich charakterem: osoby uzyskujące niski przychód z działalności gospodarczej są w nieproporcjonalnie wysokim stopniu obciążone wymiarem obowiązkowych składek, podczas gdy samozatrudnieni uzyskujący wysoki przychód, o ile nie zadeklarują wyższej podstawy wymiaru, odprowadzają do systemu ubezpieczeń społecznych stosunkowo niskie składki, przyczyniając się do pogorszenia jego kondycji finansowej.

Konsekwencje zdrowotne wynikające $\mathrm{z}$ wykorzystania atypowych form zatrudnienia wykraczają poza problem pozbawienia ubezpieczenia zdrowotnego pracujących na podstawie umowy o dzieło. Niepewność jutra wynikająca z ograniczenia lub braku ochrony trwałości zatrudnienia prowadzi do stresów, które z kolei mogą stać się przyczyną chorób układu krążenia. Zatrudnienie niepracownicze wiąże się z brakiem badań profilaktycznych prowadzonych w ramach medycyny pracy oraz urlopów wypoczynkowych ${ }^{58}$. Czynniki te dodatkowo negatywnie oddziałują na kondycję zdrowotną pracowników gorszego segmentu rynku pracy. Skutki braku

\footnotetext{
${ }_{55}$ R. Bakalarczyk, Śmieciowe życie na śmieciowej umowie, „Nowy Obywatel” 2014, nr 4(15), s. 50-57.

${ }^{56}$ Ustawa $z$ dnia 23 października 2014 r. o zmianie ustawy o systemie ubezpieczeń społecznych oraz niektórych innych ustaw, Dz. U. 2014, poz. 1831.

57 Ustawa z dnia 13 października 1998 r. o systemie ubezpieczeń społecznych, Dz. U. 1998, nr 137, poz. 887.

${ }^{58}$ R. Bakalarczyk, op.cit.
} 
profilaktyki i mniej korzystnych warunków zatrudnienia dla zdrowia fizycznego i psychicznego to również wyższe koszty leczenia, ponownie uderzające w finanse systemu zabezpieczenia społecznego.

$* * *$

W niniejszym artykule konsekwentnie koncentrowano się na tych elastycznych formach świadczenia pracy, które umożliwiają pracodawcom redukcję kosztów zatrudnienia i bardziej swobodne kształtowanie jego wielkości. Stąd negatywny, czy wręcz alarmistyczny, wydźwięk opracowania. Jednakże w świetle dostępnych statystyk mówiących o znacznej skali rozpowszechnienia poszczególnych rozwiązań na polskim rynku pracy, a także w związku ze zidentyfikowaniem licznych niekorzystnych skutków, jakie pociąga dla pracowników ich stosowanie, należy prowadzić dyskusję nad kształtem rozwiązań, które pozwoliłyby ograniczać nadużycia i zapewniać minimalny poziom bezpieczeństwa socjalnego osób dotykanych tymi skutkami. Tym bardziej, że - jak wskazano wyżej - ujemne konsekwencje nadmiernej elastyczności dotyczą również systemu zabezpieczenia społecznego, kondycji zdrowotnej społeczeństwa czy stanu gospodarki. Niewątpliwie w wielu wypadkach trudna sytuacja ekonomiczna polskich przedsiębiorstw (zwłaszcza sektora MSP), funkcjonujących $\mathrm{w}$ nie zawsze przejrzystym otoczeniu prawnym, dysponujących ograniczonym kapitałem i utrudnionym dostępem do zewnętrznych źródeł finansowania, a zarazem wystawionych na konkurencję firm zagranicznych, może zmuszać do prób poszukiwania oszczędności poprzez obniżanie standardów zatrudnienia. Nie może to jednak uderzać w sytuację świadczących pracę, zwłaszcza że ich gorsze warunki bytowe i jakość życia to w konsekwencji niższy popyt na wyroby i usługi rodzimych przedsiębiorców oraz ucieczka za granicę wykwalifikowanych pracowników.

\section{Bibliografia}

Bakalarczyk R., Śmieciowe życie na śmieciowej umowie, „Nowy Obywatel” 2014, nr 4(15).

Castells M., Społeczeństwo sieci, Wydawnictwo Naukowe PWN, Warszawa 2010.

Czarzasty J., Rola układów zbiorowych pracy w Polsce, raport sporządzony dla Eurofound, https://eurofound.europa.eu/sites/default/files/ef_files/eiro/2002/10/feature/pl0210108fpl. doc, dostęp 23.03.2015.

Deregulacja polskiego rynku pracy, red. K.W. Frieske, IPiSS, Warszawa 2003.

Esping-Andersen G., Trzy światy kapitalistycznego państwa dobrobytu, Difin, Warszawa 2010.

Frieske K.W., Dwa oblicza rynku pracy, w: A. Kojder, Jedna Polska? Dawne i nowe zróżnicowania społeczne, Wydawnictwo WAM, Kraków 2007. 
Gardawski J., Korporacje transnarodowe a Europejskie Rady Zakładowe w Polsce, Oficyna Wydawnicza SGH, Warszawa 2007.

Grzegorczyk J., Koniec etatu?, „Obywatel” 2010, nr 2.

Konieczna-Sałamatin J., Pańków M., Stasiowski J., Analiza struktury, uwarunkowań i perspektyw rozwoju alternatywnych form zatrudnienia na Dolnym Śląsku. Raport Końcowy, Dolnośląski Wojewódzki Urząd Pracy, Wałbrzych 2011.

Kowalik T., www.polskatransformacja.pl, Wydawnictwo MUZA, Warszawa 2009.

Kryńska E., Elastyczność zatrudnienia na polskim rynku pracy, „Polityka Społeczna” 2007, nr 11-12.

Łapiński K., Umowa o pracę na czas określony w polskim i unijnym prawie pracy, Lex a Wolters Kluwer business, Warszawa 2011.

Machol-Zajda L., Rozwój elastycznych form pracy, „Zarządzanie Zasobami Ludzkimi” 2008, nr 5.

Olszewski J., System pracy w warunkach globalnego społeczeństwa informacyjnego, Wydawnictwo Uniwersytetu Ekonomicznego w Poznaniu, Poznań 2013.

Reda A., Praca tymczasowa na podstawie umowy cywilnoprawnej, „Praca i Zabezpieczenie Społeczne" 2012, nr 9.

Sennett R., Korozja charakteru. Osobiste konsekwencje pracy w nowym kapitalizmie, Wydawnictwo Literackie MUZA SA, Warszawa 2007.

Sprawozdanie z działalności Państwowej Inspekcji Pracy w 2013 r., Główny Inspektorat Pracy, Warszawa 2014.

Standing G., Prekariat. Nowa niebezpieczna klasa, Wydawnictwo Naukowe PWN, Warszawa 2014.

Suknarowska-Drzewiecka E., Długoterminowa umowa o pracę na czas określony, „Monitor Prawa Pracy" 2010, nr 5.

Trade union membership 2003-2008, Eurofound, Dublin 2009, http://eurofound.europa. eu/sites/default/files/ef_files/docs/eiro/tn0904019s/tn0904019s.pdf, dostęp 23.03.2015.

Trawińska M., Minimum wage data shocks experts, raport sporządzony dla Europejskiej Fundacji na rzecz Poprawy Warunków Życia i Pracy (Eurofound), http://eurofound.europa. eu/observatories/eurwork/articles/working-conditions/minimum-wage-data-shocks-experts, dostęp 23.03.2015.

Woś R., Dziecięca choroba liberalizmu, Wydawnictwo Studio Emka, Warszawa 2014.

Wratny J., Elastyczne formy zatrudnienia w perspektywie polskiego prawa pracy, w: Elastyczne formy pracy. Szanse i zagrożenia, red. C. Sadowska-Snarska, Wydawnictwo Wyższej Szkoły Ekonomicznej w Białymstoku, Białystok 2008.

Wspólne zasady wdrażania modelu flexicurity, Komunikat Komisji do Parlamentu Europejskiego, Rady, Europejskiego Komitetu Ekonomiczno-Społecznego i Komitetu Regionów, Bruksela 2007, www.mpips.gov.pl/userfiles/File/flexi_komunikat_ue.pdf, dostęp 23.03.2015.

Zarzycka E., Polak elastyczny, „Solidarność” 2008, nr 34.

Zatrudnienie na czas określony w polskiej gospodarce, red. M. Bednarski, K.W. Frieske, IPiSS, Warszawa 2012. 